Volume 13

Issue 3 Critical Genocide and Atrocity

Prevention Studies

$12-20-2019$

\title{
Book Review: The Politics of Annihilation: A Genealogy of Genocide
}

Jeffrey Bachman

American University

Follow this and additional works at: https://digitalcommons.usf.edu/gsp

\section{Recommended Citation}

Bachman, Jeffrey (2019) "Book Review: The Politics of Annihilation: A Genealogy of Genocide," Genocide Studies and Prevention: An International Journal: Vol. 13: Iss. 3: 168-170.

DOI:

https://doi.org/10.5038/1911-9933.13.3.1713

Available at: https://digitalcommons.usf.edu/gsp/vol13/iss3/15

This Book Review is brought to you for free and open access by the Open Access Journals at Digital Commons @ University of South Florida. It has been accepted for inclusion in Genocide Studies and Prevention: An International Journal by an authorized editor of Digital Commons @ University of South Florida. For more information, please contact digitalcommons@usf.edu. 


\title{
Book Review: The Politics of Annihilation: A Genealogy of Genocide
}

\author{
Jeffrey Bachman \\ American University School of International Service \\ Washington, District of Columbia, USA
}

The Politics of Annihilation: A Genealogy of Genocide

Benjamin Meiches

Minneapolis, University of Minnesota Press, 2019

338 Pages; Price: \$28.00 Paperback

Reviewed by Jeffrey Bachman

American University School of International Service

In his 2012 article, "Critical Genocide Studies," Alexander Laban Hinton wrote, "As the outlines of the field [of genocide studies] emerge more clearly, the time is right to engage in critical reflections about the state of the field, or what might be called critical genocide studies. The goal is not to be critical in a negative sense but to consider, even as a canon becomes ensconced, what is said and unsaid, who has voice and who is silenced, and how such questions may be linked to issues of power and knowledge." 1

In his significant text, The Politics of Annihilation: A Genealogy of Genocide, Benjamin Meiches answers this call with a novel approach to analyzing the ways in which ideas, concepts, and understandings about what genocide is and how it is to be prevented have become entrenched politically and intellectually. At the center of this analysis is what Meiches refers to throughout his text as the hegemonic understanding of genocide. For Meiches the hegemonic understanding of genocide is formed by the "dominant series of assumptions and practices" that exist as part of a belief that "genocide is a self-evident concept...supported by strong presumptions about meaning, language, and law." ${ }^{2}$ Furthermore, the hegemonic understanding is not limited to a single definition of the concept of genocide, but rather "a form of discursive practice within the politics of genocide, which operates as if the concept of genocide may be defined by more or less objective criteria, has stable political implications, and can be used to set up a static taxonomy or hierarchy for governing mass atrocities." 3

Using what Michel Foucault describes as genealogy, Meiches set out to evaluate the process by which the concept of genocide has become intelligible as such in the present. The Politics of Annihilation is divided into two main parts, "The Concept and Its Power" and "The Politics of Genocide." In the first part, Meiches explores the different components of the concept of genocideincluding groups, mereology (or the part/whole distinction), destruction, and desire - as they have developed, evolved, interacted, and become generally accepted. Meiches writes that it is through the interactions of these components across time that "render the concept intelligible, meaningful, and actionable in global politics." ${ }^{4}$ As Meiches demonstrates in the four chapters that make up the first part of his text, it is also through interactions with the four components of the concept of genocide in politics and law that a hegemonic understanding of genocide has emerged, one that synonymizes genocide with mass killing when perpetrated through direct physical violence against ethno-religious groups.

As Meiches articulates, this is problematic because it is exclusionary; it places groups and identities that do not conform to those protected outside the possibility of genocide, while also restricting genocide to mean only one type of violence and its variants. Relatedly, it also produces a

\footnotetext{
${ }^{1}$ Alexander Laban Hinton, “Critical Genocide Studies," Genocide Studies and Prevention 7, no. 1 (2012), 4.

${ }^{2}$ Benjamin Meiches, The Politics of Annihilation: A Genealogy of Genocide (Minneapolis: University of Minnesota Press, 2019), 12.

${ }^{3}$ Ibid.

${ }^{4}$ Ibid., 32.
}

Jeffrey Bachman. "Book Review: The Politics of Annihilation: A Genealogy of Genocide 13, 3(2019): 168-170. @2019 Genocide Studies and Prevention. 
positive feedback loop in which the hegemonic understanding of genocide is constantly reproduced and, therefore, perpetuated. As Meiches argues, by excluding some groups from the Genocide Convention's protection and reifying nationality, ethnicity, race, and religion as the substantial categories of group life in global politics, the Genocide Convention "constitutes them as standards for the expression of threatened identity. These standards generate powerful incentives for groups to represent themselves (or be represented) within these terms." ${ }^{5}$

In the second part of his book, Meiches' connects the politics of genocide, the "multiplicity of discourses, contestations, language games, ruminations, affective and rhetorical strategies, maneuvers, and dissimulations surrounding the concept of genocide," to genocide as politics, "a mode of political practice or activity that employs a variety of forms of mass violence to target and destroy groups." ${ }^{\prime 6}$ In the final three chapters of The Politics of Annihilation, Meiches sets out to evaluate the role of the hegemonic understanding of genocide in the creation of international institutions, international law, and genocide scholarship, which themselves seek to "fix great power politics, norms, institutions, or media sources to align the concept of genocide with the expectations of the performative power declarations that genocide ought to possess." ${ }^{7}$

Meiches successfully addresses the ways in which the hegemonic understanding of genocide regulates what are viewed as credible and accurate invocations of genocide, which has a productive effect on imagined responses to genocide. Conversely, as Meiches argues, by regulating when genocide may be invoked, the hegemonic understanding "reifies political domination by excluding a priori many claims regarding the intelligibility of destructive processes." Furthermore, the appearance of genocide serves as evidence of a need to reformulate the international system in a manner that is more "attuned to the types of harms envisioned by the hegemonic understanding." 8 In other words, the hegemonic understanding of genocide, involving the mass killing of members of a (legally) protected group, necessitates the emergence of new mechanisms of political control to obstruct occurrences of genocide, including through engagement in armed conflict. As Meiches notes, the reconceptualization of war as a method of humanitarianism "marks a significant break from the prevailing definition of armed conflict by situating the actors, relations, and ethics in new domains." 9 Perhaps worryingly, depending on the audience, this new form of humanitarian governance, writes Meiches, dislocates localized efforts at genocide prevention while legitimizing the development of new techniques of "humanitarian" violence.

The role of power relations in the development and maintenance of what Meiches refers to as the hegemonic understanding of genocide recalls for me David Luban's "Just War and Human Rights." 10 Published in 1980, Luban argues that some states lose their legitimacy and, therefore, their sovereignty, when they violate the rights of their citizens. Meanwhile, states that retain their legitimacy hold the moral authority to decide when other states have lost their legitimacy and to intervene on behalf of the persecuted population. Luban's article contributes neatly to the hegemonic understanding of genocide by excluding some forms of violence, those more likely to be associated historically or presently with settler and imperial western states, while focusing his attention on violence of the dictatorship as that which may be justly responded to with war by legitimate, i.e. western, states. The hegemonic understanding sits as a foundation to a framework that attaches genocide to a particular meaning, not exactly wholly static, but also not malleable in the way that Lemkin intended. The possibility of genocide is limited to the hegemonic understanding and it is from this understanding that the political possibility for prevention of genocide is generated. The hegemonic understanding of genocide is then constantly reproduced and perpetuated by participation of various actors in international institutions, legal forums, and elements of genocide scholarship that were themselves created out of the hegemonic understanding of genocide.

\footnotetext{
${ }^{5}$ Ibid., 59.

${ }^{6}$ Ibid., 9.

${ }^{7}$ Ibid., 173.

${ }^{8}$ Ibid., 174 .

${ }^{9}$ Ibid., 175 .

${ }^{10}$ David Luban, "Just War and Human Rights," Philosophy and Public Affairs 9, no. 2 (1980), 160-181.
} 
The value of Meiches' research is extensive. It offers significant evidence in support of many of the emerging critiques of the field of genocide studies. Like the dominance of Holocaust studies before, the hegemonic understanding of genocide is stifling. It is a dictatorial and exclusionary concept, as such it denies space for evolution, imagination, and possibility. In response to Meiches' work, one might question whether there is anything wrong, per se, with a hegemonic concept of genocide. After all, hegemonies do not materialize out of thin air and a hegemonic understanding creates necessary boundaries that differentiate genocide on one side and something else, whether crimes of war or crimes against humanity and other forms of persecution on the other. However, as Meiches' thoroughly delineates, the hegemonic understanding of genocide is problematic-a consequence of the "politics of genocide." It gives inalterable and supposedly objective meaning to a concept that is fluid by nature and malleable by necessity.

Meiches also inspires reflective and introspective thinking. Genocide scholars ought to read this book because it is not possible to do so without questioning our assumptions about the meaning of genocide-what is included in one's understanding and what is excluded - and what this means in relation to the prevention of genocide - which cases warrant recognition and reaction. Furthermore, Meiches' book will motivate its readers to consider the ways in which we contribute to the maintenance of a hegemonic understanding of genocide. Even those of us who seek to challenge its hegemony may find that we inadvertently and unconsciously reinforce elements of its dominance simply by approaching the subject of genocide through culturally embedded biases that we are often aware of and, much to our vexation, have unintentionally internalized. In this regard, Meiches has ably contributed to the field of (critical) genocide studies in ways that extend beyond the singular uniqueness of his text. Indeed, it is fair to expect that The Politics of Annihilation will inspire and inform the works of scholars yet to come. 